\title{
Review of nursing diagnosis validation studies: caregiver role strain
}

\author{
Revisão dos estudos de validação do diagnóstico de \\ enfermagem: tensão do papel de cuidador \\ Revisión de los estudios de validación del diagnóstico de \\ enfermería: cansancio del rol de cuidador

\section{Tânia Marlene Gonçalves Lourenço a,b \\ Rita Maria Sousa Abreu-Figueiredo ${ }^{a}$} \\ Luís Octávio de Sác
}

How to cite this article: Lourenço TMG, Abreu-Figueiredo RMS, Sá LO. Review of nursing diagnosis validation studies: caregiver role strain. Rev Gaúcha Enferm. 2020;41:e20190370. doi: https://doi.org/10.1590/19831447.2020.20190370
¿ Escola Superior de Enfermagem São José de Cluny. Funchal, Portugal

${ }^{b}$ Center for Health Technology and Services Research (CINTESIS), NursID - Innovation \& Development in Nursing Research Group. Porto, Portugal

Universidade Católica Portuguesa (UCP), Instituto de Ciências da Saúde, Centro de Investigação Interdisciplinar em Saúde (CIIS). Porto, Portugal

\section{ABSTRACT \\ Objective: To analyze the nursing diagnosis NANDA-I - Caregiver Role Strain validation studies.}

Methods: Integrative literature review. Research of studies carried out between 2000 and 2018 with the descriptors: caregivers, nursing diagnosis and validation study in the following databases: Web of Science, EBESCOhost, Scielo Brasil and Portugal, LILACS, RCAAP, CAPES, NANDA-I website, and in the bibliographic references of the articles. Articles in Portuguese, English or Spanish were included.

Results: The sample consisted of seven validation studies, with heterogeneity in the methodologies used. The populations where the diagnosis was clinically validated focused on caregivers for the elderly and people with chronic illness. The most prevalent defining characteristics were Stress and Apprehension related to the future.

Conclusions: This diagnosis requires further validation studies among different populations in search of greater accuracy and a reduction in the number of defining characteristics, facilitating the use of taxonomy.

Keywords: Nursing diagnosis. Caregivers. Validation study.

\section{RESUMO}

Objetivo: Analisar os estudos de validação do diagnóstico de enfermagem NANDA-I - Tensão do Papel de Cuidador.

Método: Revisão integrativa da literatura. Pesquisa de estudos realizados entre 2000 e 2018 com os descritores: cuidadores, diagnóstico de enfermagem e estudo de validação nas bases de dados: Web of Science, EBESCOhost, Scielo Brasil e Portugal, LLLACS, RCAAP, CAPES, site da NANDA-I, e nas, referências bibliográficas dos artigos. Foram incluídos artigos em português, inglês ou espanhol. Resultados: A amostra foi constituída por sete estudos de validação, sendo verificada heterogeneidade nas metodologias utilizadas. As populações onde o diagnóstico foi validado clinicamente centraram-se em cuidadores de idosos e pessoas com doença crónica. As características definidoras mais prevalentes foram o Estresse e a Apreensão relacionada com o futuro.

Conclusões: Este diagnóstico necessita outros estudos de validação em diferentes populações visando uma maior acurácia e uma redução do número de características definidoras, facilitando o uso da taxonomia.

Palavras-chave: Diagnóstico de enfermagem. Cuidadores. Estudo de validação.

\section{RESUMEN}

Objectivo: Analizar los estudios de validación del diagnóstico de enfermería NANDA-I - cansancio del rol de cuidador Método: Revisión integradora de la literatura. Estudios de investigación llevados a cabo entre 2000 y 2018 con los descriptores: cuidadores, diagnóstico de enfermería y estudio de validación en las bases de datos: Web of Science, EBESCOhost, Scielo Brasil y Portugal, LILACS, RCAAP, CAPES, sítio web de NANDA-I, y en las referencias bibliográficas de los artículos. Se incluyeron artículos en portugués, inglés o español.

Resultados: La muestra consistió en siete estudios de validación, se encontró heterogeneidad en las metodologías utilizadas. Las poblaciones donde el diagnóstico fue validado clínicamente se centraron en los cuidadores de ancianos y personas con enfermedades crónicas. Las características definitorias más prevalentes fueron el estrés y la aprensión relacionadas con el futuro.

Conclusiones: Este diagnóstico requiere más estudios de validación en diferentes poblaciones con el objetivo de una mayor precisión y una reducción en el número de características definitorias, facilitando el uso de la taxonomía. Palabras clave: Diagnóstico de enfermería. Caregivers. Estudio de validación. 


\section{口INTRODUCTION}

Along with improving quality of life, the focus on health and social policies has increased the longevity of populations. If, on the one hand, living longer is the sign of a civilization's evolution, on the other, this increase in average life expectancy entails several less positive repercussions. These repercussions include higher social and economic costs, increased prevalence of chronic diseases, greater comorbidities, greater dependence, and consequently, longer and increasingly differentiated care needs. Such care is essentially provided by family members or significant persons close to the patient, called informal caregivers. The Global Strategy and Action Plan on Aging and Health 2016-2020 (1) includes informal caregiver support as one of the key actions (in one of its five strategic objectives). This support should be guided by the best available scientific evidence. The investigation on informal caregivers has been vast. Numerous studies have been carried out, mainly in the last 20 years, focusing on caregiver burnout, stress and depression ${ }^{(2)}$. We can define informal caregivers as those who provide unpaid care, which is instrumental and emotional in nature ${ }^{(3)}$. Despite the diversity of research areas on caregivers, most studies have focused on burnout ${ }^{(4)}$. Care receiver who present this condition are very diverse, including people with chronic illness ${ }^{(5-6)}$, physical dependence ${ }^{(7)}$, mental disease $\mathrm{e}^{(8-9)}$, oncological disease $\mathrm{e}^{(10-11)}$, carriers of the Human Immunodeficiency Virus infection/ Acquired Immune Deficiency Syndrome ${ }^{(12-13)}$ and also palliative patients ${ }^{(14-15)}$. The impact of this burden on health has also been widely studied, mainly regarding the mental health of caregivers with a higher probability of developing depression or anxiety ${ }^{(16-17)}$. Recent studies support that caregivers do not have a greater risk of physical health deterioration when compared to non-caregivers, but caregivers with burden do ${ }^{(18-19)}$. Spiritual well-being and quality of life is similarly related to caregiver burden ${ }^{(20-21)}$. Caring for a relative or significant person at the end of their life implies changes in several dimensions of the caregiver's own life, which needs to be reorganized both at a personal, family and professional level. This new role can prevent the caregiver from having time for themselves and the rest of the family, making leisure time scarce. Physical and emotional health problems may worsen and conflicts in relationships may arise. When the caregiver feels tired, worn out, with a conflict between the care to be provided and the satisfaction of their needs, we are faced with the phenomenon of Caregiver Role Strain, which needs to be diagnosed. Although the phenomenon of caregiver overload is widely studied, its perspective as a nursing diagnosis has been scarce. Integrated in one of the stages of the nursing process, which allows the proper planning of the interventions to be implemented, the nursing diagnosis reflects the clinical decision of the nurse regarding a certain health condition or disease of an individual, family, group or community. Based on the above, it is noted that there is a need to intervene with informal caregivers to prevent and diagnose Caregiver Role Strain in its early stages. This phenomenon appears in NANDA International, Inc. (NANDA-I) 2018-20 as the diagnosis label "Caregiver Role Strain" (00061)

(22) conceptually defined as the difficulty in fulfilling care responsibilities, expectations and/or behaviors for family or significant others. It presents an evidence level of 2.1 (varies between 1.1 and 3.4), which means accepted for publication and inclusion in the NANDA-I taxonomy with title, definition, defining characteristics and risk factors or related to literature. This diagnosis has been in the taxonomy for about 27 years, having been introduced in 1992 and revised in 1998, 2000, and more recently in 2017. Currently, it has a high number of defining characteristics (DC)34, and related factors (RF) 53. This last review only slightly changed the definition, and nine factors related to the existing ones were added. In this edition, two new diagnostic components were added: at-risk populations and associated conditions, in order to facilitate the diagnostic activity of nurses ${ }^{(22)}$. Eight populations at risk and nine associated conditions emerged for the diagnosis under analysis. Regardless of the last, and recent review, the diagnosis continues to present a low level of evidence, needing to be validated to contribute to a better diagnostic accuracy. The validation studies of nursing diagnoses, in addition to promoting a refinement and improvement of classifications, contribute to an evidence-based practice ${ }^{(22-23)}$. We began this integrative literature review based on these assumptions, with the following objective: to analyze the validation studies of the Caregiver Role Stain diagnostic. The intention is to provide a synthesis of the knowledge already produced in this field, capable of increasing the level of evidence of this diagnosis, as well as sustaining future research in the field of taxonomies and classifications in nursing, more specifically in this diagnosis.

\section{METHOD}

This is an integrative literature review study ${ }^{(24-26)}$. Six steps were used: guiding question and descriptors, literature search with the definition of inclusion and exclusion criteria, categorization of the studies, evaluation of studies to be included, interpretation of results and synthesis of knowledge. First, the guiding question was defined according to the objective: what validation studies on the diagnosis of Caregiver Role Strain were carried out? The descriptors 
used were Health Sciences Descriptors - DeCS: cuidadores, diagnóstico de enfermagem e estudos de validação, and the Medical Subject Headings - MeSH: caregivers, nursing diagnosis and validation studies. The databases used were Web of Science, Scielo Brasil and Portugal, EBSCOhost (CINAHL Plus with Full Text; MEDLINE with Full Text; MedicLatina; PsycARTICLES; Academic Search Complete; PsycBOOKS) and Latin American and Caribbean Literature were searched in Health Sciences-LILACS, in the area reverted to the members of the NANDA-I website, in the Open Access Scientific Repository in Portugal - RCAAP, in the theses and dissertations catalog of the Coordination for the Improvement of Higher Education Personnel-CAPES, and in bibliographic references of articles. The search was carried out in September 2018, encompassing studies carried out 2000, establishing the time limit as such. The year was chosen for it being this diagnostis' most significant review date, coinciding with the transition from the Taxonomy I structure to Taxonomy II structure of the 2001-2002 NANDA edition. Inclusion criteria encompassed studies dealing with the validation of the diagnosis of the Caregiver Role Stain, searched for in Portuguese, English or Spanish, and those that, despite dealing with the diagnosis under study, did not correspond to the guiding question were excluded. The articles were selected by two reviewers by reading the title, followed by the summary and finally, the full text, with those that did not meet the inclusion and exclusion criteria being eliminated in each stage At this stage of the review, the computer program EndNote version X7 was used to build the review library, which facilitated the elimination of duplicate articles. After selecting the studies included in this review, a database was built using the Excel software (Microsoft Office - Version 2016) to organize the information extracted from each study. This phase involved the development of a data collection instrument to extract the key information from each selected article. The instrument covered the following items: authors, date, article title, magazine or source, country of origin, type of validation (content or clinic), methodology, instruments, population, main results and conclusions. Subsequently, a synthesis of the findings obtained in each study regarding the DCs was made, categorizing them into major, minor and irrelevant, depending on the available data. Although not all studies use this nomenclature, this proposal was chosen ${ }^{(23)}$ because it considered to be the most appropriate way to compare the data. The major corresponded to the DC classified in the studies as: major, principais, maiores or statistically significant; minor were those reported as: secondary, menores, minor and not statistically significant; irrelevant ones referred to: irrelevant, excluded and absent.

\section{RESULTS}

428 references were identified in the databases, and 23 in other literature sources (article references) totaling 451. Of that number, 201 were found in duplicate by EndNote. 32 were selected by title and reading of abstracts, 25 references were selected for full reading. 18 references were then excluded based on pre-established criteria, leaving seven references included in this review. These data can be consulted through Figure 1, diagram of the steps for selecting the studies included in the review ${ }^{(26)}$.

The analysis of publications regarding title, date, country of origin of the validation, authors and area of training was summarized in Chart 1. The studies are numbered and ordered according to their respective decreasing publication date. Regarding the publication dates, it was noted that three of the studies were published less than five years ago, and with regard to the country where the validation was carried out, Brazil was the country with the largest number, totaling three references. All of the study authors were nurses, and two studies were co-authored by a doctor ${ }^{(27-28)}$. One of the investigations was a doctoral thesis in nursing ${ }^{(29)}$, all others are not associated with academic work.

The aim was to discover the type of validation and methodology used, as well as the main results. These data are represented in Chart 2. It was found that two studies were for content validation ${ }^{(29-30)}$, and six for clinical validation. It should be noted that one of the studies carried out both types of validation ${ }^{(29)}$. The methodology used was varied, as shown in Chart 2. Different content and clinical validation models of the diagnoses were used, some already widely used $^{(27,29-31)}$, others with more recent approaches in clinical validation of nursing diagnosis ${ }^{(27)}$, such as diagnostic accuracy measures ${ }^{(32)}$, and still others, who resorted to statistical measures ${ }^{(28,33)}$.

Investigating nurses who participated in the content validation studies were selected through pre-established criteria ${ }^{(23)}$. This validation was carried out after a literature review for the conceptual and operational definition of the DC and RF. The authors reported that the selection of specialists to perform the validation proved to be difficult, as finding nurses with pre-established criteria and interested in the investigation was a challenge. The populations studied in the clinical validation surveys were always caregivers of dependent people or those with chronic illness, the sample size varied between 40 and 225 caregivers. In all studies, most caregivers were female, with a percentage between $71.0 \%$ and $91.8 \%$. Regarding the average or mean age, it ranged between 45 and 65 years. It was also found that the most frequent relationship was being the son or daughter 


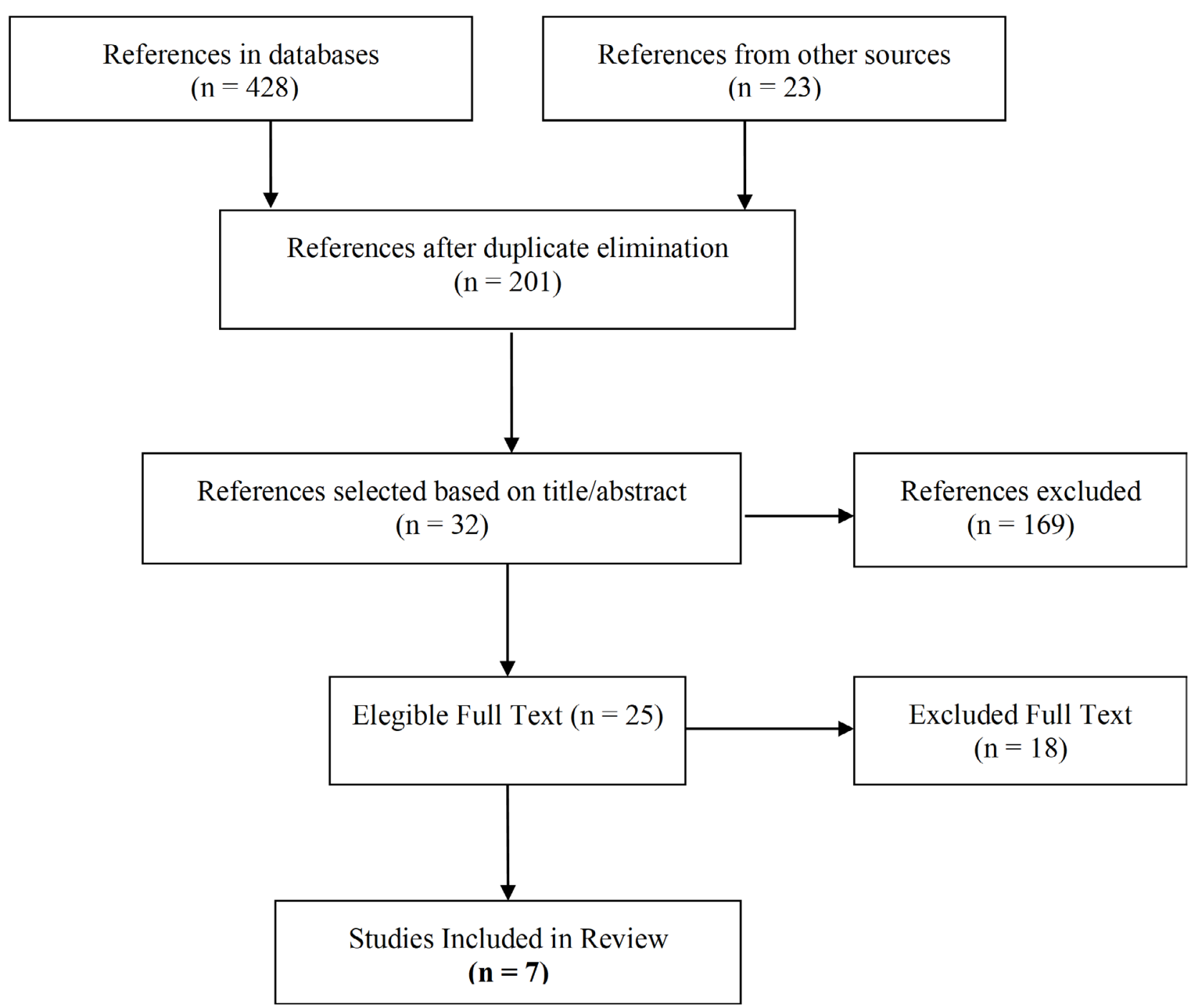

Figure 1 - Diagram for selecting review studies

Source: Research data.

of the care receiver, varying between $43.3 \%$ and $65.3 \%$. Not all studies provide data on the duration as caregiver. Of those who do, it varies between 2 to 6 years. Regarding employment, of the three studies that expose these data, it was found that the majority had no formal job, varying between 67.5 and $85.5 \%$. In the only study that validated the content of the diagnostic statement and its definition ${ }^{(29)}$, it was simply suggested to change the definition. The proposal suggested by the experts was the following: "dynamic state of alteration of the caregiver's multidetermined and cumulative biopsychosocial well-being resulting from the process of caring for a relative or other significant person". Regarding the DC of the diagnosis, no study has fully maintained the DC provided for in NANDA-I. In five of the studies ${ }^{(28-29,31-33)}$, at least 10 of the DCs proposed by this taxonomy were eliminated or considered irrelevant. On the other hand, new DCs and related factors, distinct from those of NANDA-I, have emerged in two studies ${ }^{(29,33)}$. Study No5 proposes the Caregiver Burden Scale as a diagnostic DC. It should be noted that this instrument has been used in almost all clinical validation studies ${ }^{(27-28,31-33)}$ to determine the presence or absence of the diagnosis in association with other measures, thus constituting one of the "Gold Standard" measurements for the presence or absence of the diagnosis. It is also verified that two studies ${ }^{(29-30)}$ found the total diagnosis score, which corresponds to the sum of the weighted means divided by the total of the DCs. The total score for specialist validation was 0.72 and 0.79 , respectively, and 0.69 in the clinical validation study. It is noteworthy that only two studies clinically validated some of the factors related to the 


\begin{tabular}{|c|c|c|c|c|c|}
\hline No. & Title & Date & Country & Authors & $\begin{array}{l}\text { Training } \\
\text { Area }\end{array}$ \\
\hline 1 & $\begin{array}{l}\text { Caregiver role strain: bi-national } \\
\text { study of content validation }{ }^{(30)}\end{array}$ & 2016 & $\begin{array}{l}\text { Columbia } \\
\text { and Brasil }\end{array}$ & $\begin{array}{l}\text { Rueda Diaz, } \\
\text { Monteiro da Cruz } \\
\quad \text { \& Gengo }\end{array}$ & Nursing \\
\hline 2 & $\begin{array}{l}\text { Validação do diagnóstico de enfermagem: } \\
\text { tensão do papel de cuidador em familiares } \\
\text { de idosos }^{(29)}\end{array}$ & 2015 & Brazil & Loureiro & Nursing \\
\hline 3 & $\begin{array}{l}\text { Clinical Validation of the Nursing } \\
\text { Diagnosis Caregiver Role Strain } \\
\text { in the Czech Republic }{ }^{(31)}\end{array}$ & 2014 & Czech Republic & $\begin{array}{l}\text { Zeleníková, } \\
\text { Kozáková } \\
\text { \& Jarošová }\end{array}$ & Nursing \\
\hline 4 & $\begin{array}{l}\text { Clinical indicators of'caregiver role } \\
\text { strain' in caregivers of stroke patients }{ }^{(32)}\end{array}$ & 2013 & Brazil & Oliveira et al & Nursing \\
\hline 5 & $\begin{array}{l}\text { Validación de las características } \\
\text { definitorias del diagnóstico cansancio } \\
\text { en el desempeño del rol de cuidador } \\
\text { en atención primaria }\end{array}$ & 2012 & Spain & $\begin{array}{l}\text { Embarba, Pintado } \\
\text { \& Carrasco }\end{array}$ & Nursing \\
\hline 6 & $\begin{array}{l}\text { Cansancio del Rol de Cuidador: } \\
\text { Validación Clínica Mediante Análisis Rasch }{ }^{(27)}\end{array}$ & 2011 & Columbia & Rueda et al & $\begin{array}{l}\text { Nursing } \\
\text { and Medicine }\end{array}$ \\
\hline 7 & $\begin{array}{l}\text { Aportación para el diagnóstico } \\
\text { de cansancio en el desempeño } \\
\text { del rol de cuidador }{ }^{(28)}\end{array}$ & 2005 & Spain & Sánchez et al & $\begin{array}{l}\text { Nursing } \\
\text { and Medicine }\end{array}$ \\
\hline
\end{tabular}

Chart 1 - Overall summary of studies included in the review Source: Research data.

diagnosis ${ }^{(28-29)}$. Chart 3 was assembled with the objective of comparing the results of the DC in the validation studies (content and clinical).

Regarding content validation, six DCs were considered major in both studies, and only one was found to be irrelevant in both. As for clinical validation studies, four DCs emerged as major in two of them, and they were: lack of time to meet personal needs, withdraws from social life, stress and changes in leisure activities. Regarding the DCs considered irrelevant, it was found that 14 were categorized in at least three of the five studies analyzed. Regarding the DCs categorized as minor, it was found that nine of them were validated in at least three studies. It should be noted that, in study $N^{\circ} .2$, 19 new DCs, not covered by NANDA-I, appeared in content validation, and 11 in clinical validation.

\section{DISCUSSION}

This review was original in its purpose, being able to aggregate the results of several studies, contributing to a synthesis of knowledge about this nursing diagnosis, which will facilitate the nurse's clinical judgment process when diagnosing the caregiver. Several diagnostic validation studies have been carried out in recent years ${ }^{(34-35)}$ where the main focus has been on the cardiovascular area. However, this review found that the diagnosis under analysis has been embraced by several researchers from different countries since its most significant review in 2000. It was also found that the interest in validating nursing diagnoses has not been restricted to academic programs ${ }^{(29)}$, or researchers ${ }^{(27,30,32)}$, also including clinical nurses, although in a smaller number ${ }^{(28)}$. 


\begin{tabular}{|c|c|c|c|}
\hline No. & Type of Validation & Population & Main Results \\
\hline 1 & $\begin{array}{c}\text { Fehring } \\
\text { Content Validation }\end{array}$ & $\begin{array}{c}6 \text { Colombian nurses and } \\
9 \text { Brazilian nurses. } \\
60.0 \% \text { doctor and } 40.0 \% \text { master }\end{array}$ & $\begin{array}{l}\text { Of the NANDA-I DCs, } 22 \text { defining } \\
\text { characteristics were identified as major, } \\
13 \text { as secondary and one irrelevant. } \\
\text { The total score of the diagnosis was 0.79. }\end{array}$ \\
\hline 2 & $\begin{array}{l}\text { Hoskins content and } \\
\text { clinical validation }\end{array}$ & $\begin{array}{c}30 \text { nurses. } \\
50 \% \text { doctors, } 30 \% \text { masters and } 20 \\
\text { with a post-doctorate } \\
40 \text { family caregivers of dependent } \\
\text { elderly persons } \\
\text { Mean age }=51.4(+/-13.7) \\
\text { years old } \\
\text { Gender }=87.5 \% \text { Female } \\
\text { Relationship }=42.5 \% \text { Child } \\
67.5 \% \text { are not employed }\end{array}$ & $\begin{array}{l}\text { The content validation resulted } \\
\text { in a new definition, new DCs and new } \\
\text { related factors. From the specialists came } \\
48 \text { DC and } 50 \text { RF, from the clinic came } \\
29 \text { DC ( } 11 \text { are not in NANDA-I) and } 28 \text { RF } \\
\text { (seven are not in NANDA-I). Total score } \\
\text { of diagnosis by specialists } 0.72 \text {, } \\
\text { and } 0.69 \text { in clinical validation. }\end{array}$ \\
\hline 3 & $\begin{array}{l}\text { Fehring's } \\
\text { Clinical Validation }\end{array}$ & $\begin{array}{c}225 \text { caregivers of dependent } \\
\text { persons in home setting } \\
\text { Mean age }=52.3(+/-13.3) \\
\text { years old } \\
\text { Gender }=80.4 \% \text { Female }\end{array}$ & $\begin{array}{l}\text { Two DCs were considered major, } 20 \text { were } \\
\text { considered minor, and } 14 \text { were irrelevant }\end{array}$ \\
\hline 4 & $\begin{array}{l}\text { Measures of diagnostic } \\
\text { accuracy (sensitivity, } \\
\text { specificity and } \\
\text { predictive values) }\end{array}$ & $\begin{array}{l}42 \text { caregivers of a person with } \\
\text { stroke sequelae } \\
\text { Mean age }=46.4(+/-15.6) \\
\text { years old } \\
\text { Gender }=90.5 \% \text { Female } \\
\text { Relationship }=45.2 \% \text { Child } \\
\text { 83.3\% are not employed }\end{array}$ & $\begin{array}{l}27 \text { DCs were found in the sample, nine } \\
\text { had } p \leq 0.05 \text {, and only four of that total } \\
\text { had high values in the diagnostic accuracy } \\
\text { measures. Ten NANDA-I DCs were not } \\
\text { identified. }\end{array}$ \\
\hline 5 & $\begin{array}{l}\text { Cross-sectional } \\
\text { descriptive study } \\
\text { with univariate and } \\
\text { multivariate analysis }\end{array}$ & $\begin{array}{c}47 \text { caregivers of } \\
\text { dependent persons } \\
\text { Mean age }=65.2 \text { years old } \\
\text { Gender }=71.0 \% \text { Female } \\
\text { Relationship }=43.3 \% \text { Child }\end{array}$ & $\begin{array}{l}11 \text { DCs did not obtain statistical } \\
\text { significance, } 16 \text { DCs were related } \\
\text { to the diagnosis, where four obtained } \\
\text { greater statistical significance. } \\
\text { They used the Zarit Scale as a DC }\end{array}$ \\
\hline 6 & Rasch Analysis & $\begin{array}{l}200 \text { caregivers of dependent } \\
\text { persons with chronic illness } \\
\text { Mean age }=45 \text { years old } \\
\text { Gender }=80.0 \% \text { Female } \\
\text { Relationship }=51.5 \% \text { Child }\end{array}$ & The Zarit scale adjusted most items. \\
\hline 7 & $\begin{array}{l}\text { Cross-section analytical } \\
\text { study }\end{array}$ & $\begin{array}{c}49 \text { caregivers of } \\
\text { dependent persons } \\
\text { Mean age }=58 \text { years old } \\
\text { Gender }=91.8 \% \text { Female } \\
\text { Relationship }=64.3 \% \text { Child } \\
\text { 85.8\% are not employed }\end{array}$ & $\begin{array}{l}\text { Association between the diagnosis } \\
\text { and } 4 \text { DC and } 5 \text { RF of NANDA-I. }\end{array}$ \\
\hline
\end{tabular}

Chart $\mathbf{2}$ - Summary of the methodology and main results of the studies Source: Research data. 


\begin{tabular}{|c|c|c|c|c|c|c|}
\hline \multirow{2}{*}{ Defining Characteristic } & \multicolumn{2}{|c|}{ Major } & \multicolumn{2}{|c|}{ Minor } & \multicolumn{2}{|c|}{ Irrelevant } \\
\hline & $\mathbf{C T}^{*}$ & $\mathrm{CL}^{\dagger}$ & $\mathrm{CT}^{*}$ & $\mathrm{CL}^{+}$ & $\mathbf{C T}^{*}$ & $\mathrm{CL}^{\dagger}$ \\
\hline $\begin{array}{l}\text { Apprehension about the future } \\
\text { regarding the caregiver's ability } \\
\text { to provide care }\end{array}$ & $(29-30)$ & (31) & & $(29,33)$ & & (32) \\
\hline $\begin{array}{l}\text { Apprehension about the future } \\
\text { regarding care receiver's health }\end{array}$ & $(29-30)$ & (31) & & $(29,33)$ & & (32) \\
\hline $\begin{array}{l}\text { Apprehension about the possible } \\
\text { institutionalization of the care receiver }\end{array}$ & (30) & & (29) & $(31,33)$ & & $(29,32)$ \\
\hline $\begin{array}{l}\text { Apprehension about the care } \\
\text { that the recipient should have } \\
\text { if the caregiver is unable to offer it }\end{array}$ & (30) & & (29) & $(29,31,33)$ & & (32) \\
\hline Difficulties completing required tasks & & & (30) & $(31,33)$ & $(29)$ & (32) \\
\hline Difficulty performing required tasks & & & & $(31-33)$ & & (29) \\
\hline $\begin{array}{l}\text { Dysfunctional changes } \\
\text { in caregiving activities }\end{array}$ & & & (30) & $(31,33)$ & $(29)$ & (32) \\
\hline Preoccupation with care routine & & (33) & $(29-30)$ & $(29,31)$ & & (32) \\
\hline Ineffective coping & (30) & & & (33) & $(29)$ & $(31-32)$ \\
\hline Stress & $(29-30)$ & $(28-29)$ & & $(31-33)$ & & \\
\hline Lack of time to meet personal needs & (30) & $(28,33)$ & & (31) & $(29)$ & \\
\hline Frustration & (30) & & (29) & & & $(29,31-33)$ \\
\hline Impatience & (30) & & (29) & (33) & & $(29,31-32)$ \\
\hline Increased emotional lability & $(29-30)$ & (32) & & $(29,31,33)$ & & \\
\hline Increased nervousness & (30) & & (29) & $(29,31-33)$ & & \\
\hline Disturbed sleep pattern & (30) & (33) & (29) & $(29,31-32)$ & & \\
\hline Sleep deprivation & $(29-30)$ & & & $(29,31,33)$ & & (32) \\
\hline Anger & & & $(29-30)$ & (33) & & $(29,31-32)$ \\
\hline
\end{tabular}

Chart 3 - Comparison of defining characteristics according to validation studies 


\begin{tabular}{|c|c|c|c|c|c|c|}
\hline \multirow{2}{*}{ Defining Characteristic } & \multicolumn{2}{|c|}{ Major } & \multicolumn{2}{|c|}{ Minor } & \multicolumn{2}{|c|}{ Irrelevant } \\
\hline & $\mathbf{C T}^{*}$ & $\mathrm{CL}^{+}$ & $\mathbf{C T}^{*}$ & $\mathrm{CL}^{+}$ & $\mathbf{C T}^{*}$ & $\mathrm{CL}^{+}$ \\
\hline Reports feeling depressed & (30) & (28) & (29) & $(29,31,33)$ & & (32) \\
\hline Somatization & (30) & & (29) & (29) & & $(31-33)$ \\
\hline Headaches & & & $(29-30)$ & (29) & & $(31-33)$ \\
\hline Diabetes & & & & (33) & (29) & $(29,31-32)$ \\
\hline Cardiovascular disease & & & (30) & & (29) & $(29,31-32)$ \\
\hline Rash & & & & & $(29-30)$ & $(29-33)$ \\
\hline Fatigue & $(29-30)$ & (29) & & (31) & & $(32-33)$ \\
\hline Hypertension & & & $(29-30)$ & (33) & & $(29,31-32)$ \\
\hline Weight change & & & $(29-30)$ & (29) & & $(31-33)$ \\
\hline Gastrointestinal upset & & & $(29-30)$ & & & $(29,31-33)$ \\
\hline Withdraws from social life & (29) & $(29,32)$ & & (31) & & (33) \\
\hline Low work productivity & & & $(29-30)$ & (29) & & $(31-33)$ \\
\hline Changes in leisure activities & (30) & $(29,32)$ & (29) & $(31,33)$ & & \\
\hline Refusals of career advancement & & & (30) & & (29) & $(29,31-33)$ \\
\hline $\begin{array}{l}\text { Reports uncertainty regarding changed } \\
\text { relationship with care receiver }\end{array}$ & & & (30) & $(31,33)$ & (29) & $(29,32)$ \\
\hline $\begin{array}{l}\text { Reports difficulty watching care } \\
\text { receiver go through the illness }\end{array}$ & (30) & & (29) & $(29,31,33)$ & & (32) \\
\hline $\begin{array}{l}\text { Reports grief regarding the changed } \\
\text { relationship with care receiver }\end{array}$ & (30) & (28) & (29) & $(31,33)$ & & $(29,32)$ \\
\hline Family conflict & (30) & & (29) & $(29,31)$ & & $(32-33)$ \\
\hline Reports concerns about family members & (30) & & (29) & $(31-33)$ & & (29) \\
\hline
\end{tabular}

Chart 3 - Cont.

Source: Research data.

${ }^{*} \mathrm{CT}$ - Content Validation, ${ }^{\dagger} \mathrm{CL}$ - Clinical Validation 
This diversity allows us to infer that there is a greater approximation, and interest, of the agents of the clinical contexts in the investigation. Despite the most widely used diagnostic validation models ${ }^{(23)}$ having suffered criticism in recent years ${ }^{(36-37)}$, they continue to thrive in the studies included in this review, as well as in other validation studies ${ }^{(34-35)}$. New methodological approaches have emerged with alternatives to these models, such as measures of diagnostic accuracy ${ }^{(38-39)}$, and these too have already been used to validate the diagnosis Caregiver Role Strain. This multiplicity of methodologies, although enriching from scientific knowledge point of view, makes it difficult to compare results in different studies, and use summary measures for diagnosis ${ }^{(36)}$. The existence of greater uniformity in the NANDA-I diagnostic validation methodology could help synthesize the knowledge produced, although this may be proved unfeasible, either due to the current methodological diversity or the evolution of knowledge, not to mention the researcher's own autonomy. Regarding the proposal to change the definition of the diagnosis, it was considered that the suggestion made in one of the studies ${ }^{(29)}$ better meets the list in the DC of the diagnosis itself, because the current definition of NANDA-|(22) is very restrictive, with the new proposal proving to be more comprehensive and representative of the phenomenon under analysis. This review presented great heterogeneity regarding the validation of the diagnostic DCs. If in some studies they were considered major, in others, they were classified as minor or even irrelevant. However, it was found that the DCs Stress and Apprehension related to the future were those considered major in most studies. These results are corroborated by those of other studies, where they verified that stress appears associated with the caregiver role ${ }^{(2,40)}$, as well as the apprehension related to the future ${ }^{(15,41)}$. Stress is almost inseparable from the diagnosis of Caregiver Role Strain. Taking care of a family member presents several psycho-emotional challenges, where personality characteristics combined with other variables, such as family support and care context, can trigger objective indicators of stress, such as cognitive, behavioral, or more subjective changes such as changes in relational patterns or a sense of loss of self that intertwine with overload. It is up to the nurse to intervene with the caregiver, facilitating stress management through psychotherapeutic interventions that facilitate the ability to adapt and solve problems, leading the caregiver to feel capable and empowered to find the most adaptive solutions to the most diverse challenges that arise during this process. Also, the DCs lack of time to meet personal needs, withdraws from social life ${ }^{(42-43)}$ and fatigue ${ }^{(44-45)}$ appear in other investigations related to the Caregiver Role Strain. Taking care of a family member causes several changes in daily life, with the concomitance of tasks to be carried out, encompassing things that range from patient care, domestic management, to work activity, among others, where the space for leisure activities, so necessary for mental well-being and reduction fatigue, ceases to exist. The caregiver is prevented from enjoying moments of leisure, either by direct impositions, such as care, or by psycho-emotional impositions, where the caregiver may perceive leisure as a "violation" of his duty to care. These changes in social life and leisure activities can also imply family conflicts, loneliness and social exclusion, leading the caregiver to feel even less motivated and involved in these activities that are so necessary for the caregiver's emotional well-being. Some of the DCs classified as minor, have been studied and related to the diagnosis under analysis by other authors, such as: disturbed sleep pattern $^{(19,46)}$, feeling depressed ${ }^{(16-17)}$, emotional lability ${ }^{(46-47)}$, changes in leisure activities ${ }^{(42-43)}$, and family conflicts ${ }^{(48-49)}$. The intervention with the caregiver must be psychotherapeutic and psychoeducational, and can be operated through the Nursing Interventions Classification (NIC) ${ }^{(50)}$ with the following interventions in the behavioral domain: caregiver support, counseling, anticipatory guidance, presence, coping enhancement, support system enhancement and guilt work facilitation. In the family domain, interventions such as: family support, family mobilization, role enhancement, family involvement promotion and respite care. The DCs classified as major should be first-line clinical indicators, and should almost always be present at diagnosis, requiring greater attention from the nurse, while minor ones may or may not be present, also requiring intervention, albeit in a less incisive manner. With the implementation of these interventions with the caregiver, we intend to achieve some of the following results using the Nursing Outcomes Classification (NOC) ${ }^{(51)}$ : caregiver well-being, personal resilience, caregiver emotional health, stress levels, leisure participation and role performance. Thus, these DCs mentioned above, may prove to be good predictors of the analyzed diagnosis, and nurses should identify them in clinical contexts with caregivers. Regarding the irrelevant DCs, it should be noted that those related to the physical component were those that appeared in greater numbers. Several studies indicate that they are a consequence of being a caregiver, and not a clinical indicator ${ }^{(18-19,49)}$. However, some of the DCs considered irrelevant in studies to validate this diagnosis, revealed themselves in other studies associated with the phenomenon, such as ineffective coping ${ }^{(7)}$ of anger ${ }^{(52)}$, or frustration ${ }^{(46)}$. This discrepancy can have several causes, requiring further investigation. We also emphasize that the DCs low work productivity and refuses career advancement, appeared as irrelevant, which may be related to the fact that most caregivers are not employed. Certain studies have shown that some caregivers left their jobs to take care of their family 
members, and when they do not, the role of caregivers has an influence on their employment positions ${ }^{(42-43)}$. It is considered that these DCs need to be independently validated in the caregivers who are, and are not employed, thus enabling a possible relationship. These DCs that have proved irrelevant need to be better studied, as they seem to be more consequences of the role itself, than diagnostic indicators. In line with this rationale, the most current version of NANDA-1(22) already excludes two of these DCs: cardiovascular disease and diabetes. Regarding the new DCs that appear in two studies, further investigation and improvement is considered urgent, given the size of the samples used, as well as the current number of DCs for these diagnoses. As for the RF, it became difficult to compare them as was done with the DCs, since only two studies carried out this analysis, and the data are so divergent that it limited this comparison. This lack of studies proved to be one of the limitations of this review. Validation studies that identify factors related to nursing diagnoses are still scarce, despite having already been studied, however, this is an area that requires investigation, as they are as relevant to a diagnosis as the DCs themselves ${ }^{(36)}$. When identifying which factors are interconnected in some way with the diagnosis is possible, it allows the nurse to better diagnose, and consequently, better intervene.

\section{CONCLUSION}

This review enabled the identification and analysis of scientific production associated with the validation of the diagnosis Caregiver Role Strain. It is considered that this study contributes to the refinement of DCs, contributing to a more accurate diagnosis, and to a better use of the NANDA-I taxonomy in the contexts of assistance, research and teaching. This review allows for a better clinical decision in nursing, allowing nurses to make a diagnostic judgment based on scientific evidence. Through the results we identified which of the 34 DCs best predict the presence of the diagnosis. The synthesis of the knowledge produced on the validation of a diagnosis had never been carried out (at least it was not located by us), thus, an unprecedented work. This study may have implications for diagnostic validation research, as the methodology used here can be replicated for other diagnoses where there is already greater production and validation terms. Also, in teaching, the findings can contribute to a better consolidation of critical thinking among students, and the improvement of intervention with caregivers. This review ends with the suggestion of other studies to validate this diagnosis in other types of populations, such as caregivers of people with mental illness, palliative illness or in children with chronic illness. Identifying what is similar and what is distinguished will open doors for a much more sensitive and specific intervention. It is also suggested that the samples should be larger and preferably randomized, so that the data are generalized, and NANDA-I increases the level of evidence of the diagnosis. It is believed that, through further investigation, and reviews like this, we will contribute to an increasingly evidence-based nursing. Nurses are certainly the most privileged professionals to diagnose and intervene in caregivers with Caregiver Role Strain, reducing the negative impact on the physical, mental, social and spiritual health of the caregiver.

\section{REFERENCES}

1. World Health Organization (CH). Global strategy and action plan on ageing and health (2016-2020). Geneve: WH0; 2016 [cited 2019 Aug 14]. Available from: https://www.who.int/ageing/WHO-GSAP-2017.pdf?ud=

2. Adelman RD, Tmanova LL, Delgado D, Dion S, Lachs MS. Caregiver burden: a clinical review. JAMA. 2014;311(10):1052-60. doi: https://doi.org/10.1001/ jama.2014.304

3. Bastawrous M. Caregiver burden: a critical discussion. Int I Nurs Stud. 2013;50(3):431-41. doi: https://doi.org/10.1016/j.jinurstu.2012.10.005

4. Viana MC, Gruber MJ, ShahlyV, Alhamzawi A, Alonso J, Andrade LH, et al. Family burden related to mental and physical disorders in the world: results from the WHO World Mental Health (WMH) surveys. Braz J Psychiatr. 2013;35:115-25. doi: https://doi.org/10.1590/1516-4446-2012-0919

5. Suri RS, Larive B, Garg AX, Hall YN, Pierratos A, Chertow GM, et al. Burden on caregivers as perceived by hemodialysis patients in the Frequent Hemodialysis Network (FHN) trials. Nephrol Dial Transplant. 2011;26(7):2316-22. doi: https://doi.org/10.1093/ndt/gfr007

6. Al-Gamal E, Yorke J. Perceived breathlessness and psychological distress among patients with chronic obstructive pulmonary disease and their spouses. Nurs Health Sci. 2014;16(1):103-11. doi: https://doi.org/10.1111/nhs.12073

7. Guedes AC, Pereira MG. Burden, coping, physical symptoms and psychological morbidity in caregivers of functionally dependent family members. Rev LatinoAm Enfermagem. 2013;21(4):935-40. doi: https://doi.org/10.1590/S0104-11 692013000400015

8. Bauer R, Döring A, Schmidt T, Spießl H. 'Mad or Bad?': burden on caregivers of patients with personality disorders. J Pers Disord. 2012;26(6):956-71. doi: https://doi.org/10.1521/pedi.2012.26.6.956

9. Vasudeva S, Sekhar CK, Rao PG. Caregivers burden of patients with schizophrenia and bipolar disorder: a sectional study. Indian J Psychol Med. 2013;35(4):352357. doi: https://doi.org/10.4103/0253-7176.122224

10. Li Y, Wang K, Yin Y, Li Y, Li S. Relationships between family resilience, breast cancer survivors' individual resilience, and caregiver burden: A cross-sectional study. Int J Nurs Stud. 2018;88:79-84. doi: https://doi.org/10.1016/j.jijurstu. 2018.08.011

11. Santo EAR, Gaíva MAM, Espinosa MM, Barbosa DA, Belasco AGS. Taking care of children with cancer: evaluation of the caregivers' burden and quality of life. Rev Latino-Am Enfermagem. 2011;19:515-22. doi: https://doi.org/10.1590/ S0104-11692011000300010 
12. Lee S, Li L, Jiraphongsa C, Rotheram-Borus MJ. Caregiver burden of family members of persons living with HIV in Thailand. Int J Nurs Pract. 2010;16(1):5763. doi: https://doi.org/10.1111/j.1440-172X.2009.01812.x

13. Mugisha J, Scholten F, Owilla S, Naidoo N, Seeley J, Chatterii S, et al. Caregiving responsibilities and burden among older people by HIV status and other determinants in Uganda. AIDS Care. 2013;25(11):1341-8. doi: https://doi.org/ 10.1080/09540121.2013.765936

14. Guerriere D, Husain A, Zagorski B, Marshall D, Seow H, Brazil K, et al. Predictors of caregiver burden across the home-based palliative care trajectory in Ontario, Canada. Health Soc Care Community. 2016;24(4):428-38. doi: https://doi.org/ 10.1111/hsc. 12219

15. Seibl-Leven M, von Reeken C, Goldbrunner R, Grau S, Ruge MI, Galldiks N, et al. Clinical routine assessment of palliative care symptoms and concerns and caregiver burden in glioblastoma patients: an explorative field study. J Neurooncol. 2018;138(2):321-33. doi: https://doi.org/10.1007/s11060-0182800-1

16. Oechsle K, Goerth K, Bokemeyer C, Mehnert A. Anxiety and Depression in Caregivers of Terminally III Cancer Patients: Impact on Their Perspective of the Patients'Symptom Burden. J Palliat Med. 2013; 16(9):1095-101. doi: https:// doi.org/10.1089/jpm.2013.0038

17. Polenick CA, Martire LM. Caregiver attributions for late-life depression and their associations with caregiver burden. Fam Process. 2013;52(4):709-22. doi: https://doi.org/10.1111/famp.12032

18. Fredman L, Cauley JA, Hochberg M, Ensrud KE, Doros G. Mortality associated with caregiving, general stress, and caregiving-related stress in elderly women: results of caregiver-study of osteoporotic fractures. J Am Geriatr Soc. 2010;58(5):937-43. doi: https://doi.org/10.1111/j.1532-5415.2010.02808.x

19. Litzelman K, Witt WP, Gangnon RE, Nieto FJ, Engelman CD, Mailick MR, et al. Association between informal caregiving and cellular aging in the Survey of the Health of Wisconsin: the role of caregiving characteristics, stress, and strain. Am J Epidemiol. 2014;179(11):1340-52. doi: https://doi.org/10.1093/aje/kwu066

20. Spatuzzi R, Giulietti MV, Ricciuti M, Merico F, Fabbietti P, Raucci L, et al. Exploring the associations between spiritual well-being, burden, and quality of life in family caregivers of cancer patients. Palliat Support Care. 2018;1-6. doi: https:// doi.org/10.1017/s1478951518000160

21. Gomez-de-Regil L, Kwapil TR, Barrantes-Vidal N. Predictors of expressed emotion, burden and quality of life in relatives of Mexican patients with psychosis. J Psychiatr Ment Health Nurs. 2014;21(2):170-9. doi: https://doi. org/10.1111/jpm. 12071

22. Herdman T, Kamitsuru S. Nursing Diagnoses: definitions and classification 20182020. New York: Thieme Publishers; 2015 [cited 2019 Aug 5]. Available from: http://www.nanda.org/nanda-i-publications/nanda-international-nursingdiagnoses-definitions-and-classification-2018-2020/

23. Fehring RJ. Methods to validate nursing diagnoses. Heart Lung. 1987 Nov;16(6): 625-9.

24. Whittemore R, Knafl K. The integrative review: updated methodology. J Adv Nurs. 2005;52(5):546-53. doi: https://doi.org/10.1111/j.1365-2648.2005.03621.x

25. Pompeo D, Rossi L, Galvão C. Integrative literature review: the initial step in the validation process of nursing diagnoses. Acta Paul Enferm. 2009;22(4):434-8. doi: https://doi.org/10.1590/S0103-21002009000400014

26. Soares CB, Hoga LAK, PeduzziM,SangaletiC,YonekuraT,Silva D. Integrativereview: concepts and methods used in nursing. Rev Esc Enferm USP. 2014;48(2):33545. doi: https://doi.org/10.1590/50080-6234201400002000020
27. Rueda LMA, Pérez CPB, Marcela D, Chávez G, Méjia MJS, Figueira FAC, et al. Caregiver Role Strain: Clinical Validation by Rasch Analysis. In: Proceedings of NANDA-I Latin American Symposium; 2011 Jun 3-4; São Paulo, Brasil. p. $125-67$.

28. Vázquez Sánchez MA, Casals SJL, Aguilar TP, Aparicio Benito BP, Estébanez $C F$, Luque $E A$, et al. Contribution to the diagnosis of caregiver role strain. Enfermeria Clinica. 2005;15(2):63-70. doi: https://doi.org/10.1016/ S1130-8621(05)71085-8

29. Loureiro LN. Validation of the nursing diagnosis "Caregiver role strain" in relatives of elderly [tese]. João Pessoa (PB): Universidade Federal da Paraíba; 2015 [cited 2019 Aug 25]. p. 196. Available from: http://tede.biblioteca.ufpb.br/handle/ tede/8177\#preview-link0:193-

30. Diaz LJ, Cruz DL, Silva RG. Caregiver role strain: bi-national study of content validation. Invest Educ Enferm. 2016; 34(2):280-7. doi: https://doi. org/10.17533/udea.iee.v34n2a07

31. Zeleníková R, Kozáková R, Jarošová D. Clinical validation of the Nursing Diagnosis Caregiver Role Strain in the Czech Republic. Int J Nurs Knowl. 2014;25(2):80-4. doi: https://doi.org/10.1111/2047-3095.12020

32. Oliveira ARS, Cordeiro RR, Carvalho VE, Costa AG, Lopes MV, Araujo TL. Clinical indicators of 'caregiver role strain' in caregivers of stroke patients. Contemp Nurse. 2013;44(2):215-24. doi: https://doi.org/110.5172/conu.2013.44.2.215

33. Embarba BA, Pintado AQ, Carrasco PR. Definitory characteristics validation of the Caregiver Role Fatigue Diagnosis in primary care. Nure Investigación. 2012 Jan/Feb [cited Aug 25, 2019];9(56):1-8. Available from: http://www.nureinves tigacion.es/0JS/index.php/nure/article/view/562/551

34. Oliveira AM, Duran ECM. Content validation of Nursing Diagnosis: an integrative review. Rev Enferm UFPE. 2015;9(8):9385-92. doi: https://doi.org/10.5205/ reuol.6812-75590-1-ED.0908sup201507

35. Oliveira AR, Costa AG, Freitas JG, Lima FE, Damasceno MM, Araujo TL. Validation of Clinical Diagnoses, Interventions and Outcomes Nursing: narrative literature review. Rev Enferm UERJ. 2013 Jan/Mar [cited 2019 Aug 25];21(1):113-20. Available from: http://www.facenf.uerj.br/v21n1/v21n1a19.pdf

36. Lopes MV, Silva VM, Araujo TL. Validation of nursing diagnosis: challenges and alternatives. Rev Bras Enferm. 2013;66(5):649-55. doi: https://doi. org/10.1590/S0034-71672013000500002

37. Lopes MV, Silva VM, Araujo TL, Silva Filho JV. Statistical characteristics of the weighted inter-rater reliability index for clinically validating nursing diagnoses. Int J Nurs Knowl. 2015;26(4):150-5. doi: https://doi. org/10.1111/2047-3095.12047

38. Oliveira-Kumakura AR, Caldeira S, Prado TS, Camargo-Figuera FA, Cruz DM, Carvalho EC. The contribution of the Rasch Model to the clinical validation of nursing diagnoses: integrative literature review. Int J Nurs Knowl. 2018; 29(2):89-96. doi: https://doi.org/10.1111/2047-3095.12162

39. Lopes MV, Silva VM, Araujo TL. Methods for Establishing the Accuracy of Clinical Indicators in Predicting Nursing Diagnoses. Int J Nurs Knowl. 2012;23(3):134-9. doi: https://doi.org/10.1111/j.2047-3095.2012.01213.x

40. Gratao AC, Vendrúscolo TR, Talmelli LF, Figueiredo LC, Santos JL, Rodrigues RA. Burden and the emocional disress in caregivers of elderly individuals. Text Context Nursing. 2012;21(2):304-12. doi: https://doi.org/10.1590/ S0104-07072012000200007

41. Hernandez M, Barrio C, Yamada AM. Hope and burden among Latino families of adults with schizophrenia. Fam Process. 2013;52(4):697-708. doi: https://doi. org/10.1111/famp.12042 
42. Mosher CE, Champion VL, Azzoli CG, Hanna N, Jalal SI, Fakiris AJ, et al. Economic and social changes among distressed family caregivers of lung cancer patients. Support Care Cancer. 2013;21(3):819-26. doi: https://doi.org/10.1007/ s00520-012-1585-6

43. Wakui T, Saito T, Agree EM, Kai I. Effects of home, outside leisure, social, and peer activity on psychological health among Japanese family caregivers. Aging Ment Health. 2012;16(4):500-6. doi: https://doi.org/10.1080/13607863.2011 .644263

44. Tang WK, Lau CG, Mok V, Ungvari GS, Wong KS. Burden of Chinese stroke family caregivers: the Hong Kong experience. Arch Phys Med Rehabil. 2011;92(9):1462-7. doi: https://doi.org/10.1016/j.apmr.2011.03.027

45. Morais HC, Soares AM, Oliveira AR, Carvalho CM, Silva MJ, Araujo TL. Burden and modifications in life from the perspective of caregivers for patients after stroke. Rev Latino-Am Enfermagem. 2012;20(5):944-53. doi: https://doi. org/10.1590/S0104-11692012000500017

46. Stamataki Z, Ellis JE, Costello J, Fielding J, Burns M, Molassiotis A. Chronicles of informal caregiving in cancer: using "The Cancer Family Caregiving Experience"; model as an explanatory framework. Support Care Cancer. 2014;22(2):435-44. doi: https://doi.org/10.1007/s00520-013-1994-1
47. Miyamoto $Y$, Tachimori $H$, Ito H. Formal caregiver burden in dementia: impact of behavioral and psychological symptoms of dementia and activities of daily living. Geriatr Nurs. 2010;31(4):246-53. doi: https://doi.org/10.1016/ jgerinurse.2010.01.002

48. Fukui C, Sakka M, Amiya RM, Sato I, Kamibeppu K. Validation of family conflict scales for family caregivers of persons with dementia in long-term care facilities and exploration of family conflicts and support. Int Psychogeriatr. 2018;30(5):749-59. doi: https://doi.org/10.1017/s1041610217002356

49. Pinquart M, Sorensen $S$. Correlates of physical health of informal caregivers: a meta-analysis. J Gerontol B Psychol Sci Soc Sci. 2007 Mar;62(2):P126-37. doi: https://doi.org/10.1093/geronb/62.2.p126

50. Bulechek et al. NIC: Classificação das Intervenções de Enfermagem. 6 a ed. Rio de Janeiro: Elsevier; 2016.

51. Moorhead et al. NOC: Classificação dos Resultados de Enfermagem. 5 a ed. Rio de Janeiro: Elsevier; 2016.

52. Wright MJ, Battista MA, Pate DS, Hierholzer R, Mogelof J, Howsepian AA. Domain-specific associations between burden and mood state in dementia caregivers. Clin Gerontol. 2010;33(3):237-47. doi: https://doi. org/10.1080/07317111003773601

\section{- Corresponding author:}

Tânia Marlene Gonçalves Lourenço

E-mail: tmlourenco@esesjcluny.pt

\section{Editor-in-chief:}

Maria da Graça Oliveira Crossetti 